\title{
EXPERIENCE WITH AN IDENTIFICATION OF EVIDENCE ABOUT MOTHER'S DRINKING ALCOHOL DURING PREGNANCY WITHIN A FRAMEWORK OF 4-DIGIT CODE DIAGNOSTICS OF FETAL ALCOHOL SYNDROME DISORDER (FASD)
}

\author{
Olga Okálová, Anna Kútniková, Zuzana Gejdošová, Miroslav Pilát
}

\begin{abstract}
In the system of social work policy, social legal protection and caregiving policy there is no comprehensive system in Slovakia which would record a biological mother's use of alcohol during pregnancy. However, the evidence of mother's use of alcohol during pregnancy has a significant impact on accurate diagnostics, therapy, education, but mainly, on social adaptability of young clients placed in foster care. As of September 2015, the number grew to 6,277 children and a trend is on the rise. FAS/FASD diagnosis is ten time greater in this group of individuals (children placed in foster care) than in the rest of population. This is caused by mothers' drinking, who are, or were, the children with FAS/FASD, as well as, later victims of long term neglect, maltreatment and sexual abuse. Many times, these women unintentionally seriously harmed their child. Specialists defined the fetal alcohol syndrome and its spectrum as a significant prenatal disease which is a preventible cause of social failure, whether due to mental retardation, or mostly because of secondary victimisation of a handicapped person. The authors of this study present results of a qualitative research, which had been performed until June 2015 on 19 clients diagnosed in the Centre for Diagnostics, Therapy and Prevention of FAS at Education Faculty, Catholic University, Ružomberok. The goal of this study is an interpretation of the 4-digit code within the Slovak system of social legal protection. As a result, the authors formulate a scientific conclusion which will benefit a diagnostic and clinical practice of Fetal alcohol syndrome and its spectrum in Slovakia.
\end{abstract}

\section{Keywords}

Fetal Alcohol Syndrome, Fetal Alcohol Spectrum disorder, diagnosis, treatment, prevention, Slovakia

\section{Introduction}

Fetal alcohol syndrome - describes a set of symptoms in children of mothers who used alcohol during pregnancy and when all symptoms are present, i.e., typical facial phenotype, CNS damage and growth deficiency. If only some of the symptoms are present, combinations of individual 
disabilities, these fall together under the umbrella of FASD diagnosis (Fetal alcohol spectrum disorder). This term includes FAS, partial FAS, static encefalopathy, neurobehavioral disorder and physical changes. Yet, it is difficult to determine which from the abovementioned diagnoses is the most accurate and explicit for behavior of an observed individual. There are more methods available. In the Centre for Diagnostics, Therapy and Prevention of FAS a patient is diagnosed by 4 criteria: alcohol exposure during intrauterine development, growth retardation, facial dysmorphia and brain damage which manifests in cognitive and behavioral area. An incidence in literature of 3-40 children to 1,000 born children has not been quantified in Slovakia (Nosková, 2014). Why then do we need to diagnose these individuals in the system of social protection?

\section{Research Focus}

Without a timely diagnostics and intervention these disabled persons represent a high risk for social system. In contrast to the rest of population, these individuals are unable to integrate within a society due to the lack of executive function development. The diagnosis "FAS Q86" has existed for 60 years in Slovakia, yet its spectrum falls into an ambiguous range of F80-F99 diagnoses. We perceive that a controversial behavior of individuals with FAS/FASD is an essential problem in a system of social integration. Brain damage is serious mostly in the cognitive and emotional area. Executive function deficiency induces an inability to remember multiple instructions as well as a failure in inhibitory control of a person, lack of understanding of abstract terms (time, money), incapability to understand cause and effect. The patient is unable to plan everyday activities, to think creatively; therefore, he/she requires a necessary and constant supervision. An irregular or changing schedule leads to an anxiety which manifests itself in an unmanageable behavior - asocial conformity.

\section{Problem of Research}

Overlapping diagnoses FAS/FASD with other health and social diagnoses complicate a setup of systemic measures. The range of overlap was studied by Cathy Bruer-Thompson, Board Vice President at MOFAS: Minnesota Organization on Fetal Alcohol Syndrome. She compared FASD with 7 other diagnoses: $\mathrm{ADD} / \mathrm{ADHD}$, sensoric disorder, autism, bipolar disorder (BPD), reactive attachment disorder (RAD), depression, oppositional behavior disorder (ODD) and even trauma and poverty (http://www.mofas. org/). However, what may help the system even today is an information that a diagnosis of FAS/FASD the most frequently and permanently harms social adaptation of an individual. Where to start? According to us the answer is clear: It is necessary to start directly in the system.

Exogenic factors of social environment are in Slovakia mostly integrated in a comprehensive diagnosis under the name: the syndrome CAN. The process is controlled by MPSVaR SR (Ministry of Work, Social Affairs and Family in Slovak Republic), by National Coordination Centre for addressing the acts of violence comitted against children. What connects a diagnosis of CAN with the diagnosis of FAS/FASD? Neglected children, who are not adequately stimulated mentally and physically, are thanks to an accurate diagnostics classified as the children with a range of FASD diagnoses. There are mostly kids who were moved from a biological family to an institutional care 
or to any other alternative care provided by social-legal protection. These inadequately treated and integrated kids exhibit tertiary disabilities. According to Streissguth (2004), these kids, when adults, are known in the system as:

$-80 \%$ is being treated in psychiatrical wards,

$-61 \%$ is failing the compulsory education,

$-60 \%$ is having criminal records,

$-50 \%$ is being imrisoned or kept in the mental institutions for mentaly ill,

$-46 \%$ is being addicted to alcohol or drugs.

When FASD is diagnosed only when the patients are 10-14 year old, it becomes difficult, if not futile, to influence a prognosis. Scientific studies have revealed that disabled kids are marginalised, leave house, have an increased incidence of mental diseases, are more often victims to substance abuse, are repeatedly involved in theft, in self-harm, or attempts in suicide, they have excessive hazardous sexual activity, they are also unable to stay at work. Early intervention has a great impact on a prognosis in improvement for these children. A target intervention may help many of these kids in their adulthood to function well.

Tertiary disability is represented in a group of individuals who are included in the statistics of Ministry of Labour, Social Affairs, and Family in SR (MPSVaR SR), Ministry of Education, Science, Research, and Sports (MSVVaS SR), Ministry of Healthcare (MZ SR), Ministry of Justice (MS SR), and in the research of non-profit organisations, such as Návrat a Úsmev ako Dar, which operate in a foster personal care. In the following example we are listing some institutions with the greatest prevalence of patients with the FASD diagnosis:

1. Ministry of Labour, Social Affairs, and Family

- According to the Act of National Council of the Slovak Republic (NR SR), no. 448/2008, on social services, as amended: The institutions where social service of crisis interventions are provided, such as, low-threshold day centers, integration centers, community centres, asylums, shelters, halfway houses, emergency housings, social services homes.

-According to the Act of NR SR, no. 305/2005, on social legal protection of kids and on social care, as amended, institutions, such as: Orphanages, orphanages for unaccompanied minors, crisis centers, resocialisation centres.

2. Ministry of Education, Science, Research, and Sports

- According to the Act of NR SR, no. 245/2008, the act on education and schooling, as amended, in the schools of educational councelling and prevention and special educational facilities: Reeducational houses and centers, diagnostic centers, medical and educational sanatoriums, centres of pedagogical-psychological councelling and prevention and special education centers for councelling.

\section{Ministry of Healthcare}

- According to the Act of NR SR, no. 578/2004, the act on health care providers, healthcare workers, healthcare professional organisations, and on the change and completion of several acts, as amended: In hospitals in psychiatrical wards and specialised healthcare facilities, such as, The Center for the Treatment of Drug Addictions.

4. Ministry of Justice

- According to the Act NR SR, no. 4/2001, the act on Prison and Court guards, as amended: Jails, prisons, jails and prisons. 
Currently, there are about 255,328 children at risk listed in social legal protection who depend on Labour, Social Affairs and Family offices and the help of offices by providing them with social services (Mrázková, \& Brennerová, 2015). We do not know an exact number of those who suffer from the permanent CNS damage. Nor do we know an amount of children with FAS/FASD diagnosis. For this reason, we cannot predict a magnitude of other risk persons in the system once they grow up. The social system of protection provides a limited range of social measures through approximately 700 professional families, 20 crisis centers and 19 resocialisation centers, and 91 orphanages (4,720 placed children). Due to an insufficient capacity the system also uses facilities in the education sphere: 5 diagnostic and 15 reeducation centers (together 478 children) (http:// www.upsvar.sk).

How to stop an unwanted process of social adaptation in these disabled persons? How can we optimalize a protection system in a relationship to FAS diagnosis? Through which measures are we able to minimalize undesirable social connections to this diagnosis? The series of studies performed in 2015 partly answer these questions.

\section{Methodology of Research}

From the position of social workers, as members of diagnostic team in Centre for Diagnostics, Prevention and Therapy of FAS we had an opportunity to meet and learn the stories of 19 children with a diagnosis of Fetal alcohol syndrome disorder.

Since the study was an initial analysis, the goal of the research was not to render a complete analysis but mostly a description of iniatial situation and a reflection on previous experiences in surveys regarding the fourth digit of the 4-digit code, i.e., information, obtained so far, on mother's use of alcohol during pregnancy. The overall quality of research material gained from the available sources depended on the conduct of preliminary analysis which we had not performed and had not payed a sufficient attention in all phases of data collection (Strauss, 1988). For this reason we had met many obstacles during the following coding.

\section{Instrument and Procedures}

Various imaging techniques was helping us to find the core of data in a systematic, repeatable and controllable way (Miles, Huberman, 1994). We sorted out collected data in a reproducible way, and then coded them (words, shortcuts, symbols depicting a semantically homogenous unit of data). According to Strauss, the coding is a general term for data conceptualisation-coding is a formulation of questions and preliminary answers (hypotheses) about cathegories and relationships between the cathegories. Strauss indicates that the term "code" is a product of this analysis - it could be a cathegory or relationship between two or more cathegories (Strauss, 1988, pp. 20-21).

We had chosen a way of an inductive approach and attempted to derive the codes from the collected documents. "In the framework of axial coding, which is the set of procedures, which, once the open coding is performed, arranged again in a new way, we had tried to create connections between cathegories." (Švaříček, Šed'ová, 2007, p. 70) Strauss and Corbinová (1999) suggest an 
implementation of a coding paradigm for a relationship formulation which Hendl assumes (2005) and which is identical with it.

We consider it to be important to at first define and distinguish a research sample from different demographic areas.

A primary analysis of information was performed from the documents of 19 children. We have obtained the documents through the admission procedures of FASD diagnostics. We performed a close inspection through coding of the written and supporting documentation consisting of several sources (copies of health documentation, written copy of a child's social report and results from psychological and special education examination, standardized questionnaires for parents about FASD diagnostics, and others). Time horizon for data collection was in the range of 03/2013 $-05 / 2015$, in irregular periodicity of 1-2 diagnostics per month. There was a sufficient time which passed from the first diagnostics of a child to the question we asked: What can we figure out from all this collected information?

From the perspective of a "SOURCE" we may assume that there were mostly report copies of health documentations, psychological, psychiatrical examinations, and statements. Due to the communication with a parent of children through emails we also added the copies of email communication.

The basic characterization of the research group from the gender perspective was the following: males $58 \%$ and females $42 \%$ from the group of 19 children.

The age of children in the time of diagnostics was within an interval $<4.3-22$ years. From the gender view, there were females in range of 4.3-19 years and males in range of 4.4-22 years of age.

From the perspective of age the majority of children were between 6.1-10 years of age.

Table no. 1 Cathegory and number of females and males

\begin{tabular}{|l|c|c|c|}
\hline Cathegory type & Number - female & Number - male & Together \\
\hline From 0-6 years & 3 & 2 & 5 \\
\hline From 6.1-10 years & 3 & 6 & 9 \\
\hline From 10.1-15 years & 1 & 1 & 2 \\
\hline From15.1-20 years & 1 & 1 & 2 \\
\hline From 20.1-more years & 0 & 1 & 1 \\
\hline
\end{tabular}

From the perspective of a family type, in which the child with FASD diagnosis was placed, we have found out that almost $83.5 \%$ of kids were placed into foster care (caregiving and adoption). Foster personal care was present only in one child. $31.5 \%$ of kids were placed in an institutional care. So far, no child in this set living in a biological family was diagnosed with FASD. 
Table no. 2 Type of care and its legal form

\begin{tabular}{|l|c|}
\hline Type of care/legal form & number \\
\hline Foster care/adoption & 5 \\
\hline Foster care/caregiving & 7 \\
\hline Foster personal care/family members & 1 \\
\hline Insitutional care/professional parenthood & 3 \\
\hline Institutional care/orphanage & 3 \\
\hline Biological family & 0 \\
\hline Together & 19 \\
\hline
\end{tabular}

In terms of ethnicity we are mostly (67 \%) talking about Roma/half Roma children whose parents were mostly of Roma origin (at least one of the parents). From the available information, $33 \%$ belonged to europoid ethnicity (assigned according to Astley, S. J., p. 23, 2004).

From the data of diagnosed children, or according to the place of birth, we had observed a higher prevalence of kids born in the region of central Slovakia (58\%), eastern region (25\%) and $17 \%$ were from other parts of Slovakia.

The overall level of child mental abilities lies in the range of mean diameter (58\%) and mild mental retardation (42\%).

As we have mentioned in the introduction of this paper, the object of our interest is the fourth digit of the code - mother's alcohol use during pregnancy.

Based on a transcript and coding of this data from the document we have identified the following findings:

\section{Data Analysis}

1. Coding focused on the cathegory "SPECIALISTS". Here, we have found out an information that a mother drank/did not drink alcohol during pregnancy.

The most occuring type of a person was the cathegory: specialists - social workers and healthcare workers. To a small extent, education workers were also present.

A. Social workers became field social workers, social workers in orphanages, social workers in social-legal child protection, social workers in crisis centers and shelters.

The information, which they confirmed/did not confirm, was recorded in the written statements we have provided:

1. "...mother was drinking during pregnancy and is continuously drinking..."

2. "...we do not posses an information which would confirm that a parent of a child was drinking alcohol..."

3. "...it has never been found out by a competent authority that the parent would have been drinking..."

4. "...mother visited pubs..." 
5. "...based on your requirement about a data submission for child $\mathrm{M}$. we are reporting that no data are stated in the documentation which would claim that mother drank alcohol..."

B. The team of healthcare providers consisted of: a pediatrician, gynecologist, nurse, psychiatrist, who were providing a written report from the healthcare documentation:

1. "...mother alcoholism..."

2. "...release from a hospital - risk of a newborn child by unspecified mother's conditions..."

3. "...biological mother of the child had likely used greater amounts of alcohol. There is an increased risk of a foetus being alcohol exposed during gravidity..."

4. "...biological mother is ethylic, abuse also during pregnancy..."

5. "...biological mother used alcohol during pregnancy..."

C. The last cathegory was formed by employees of Ministry of Education: a psychologist and special educator have recorded the following:

1....from the interview with a caregiver I cite: "the child in a care, mother used alcohol longterm..."

2. "...according to health documentation - risk of a child in the early development by mother's neglect..."

2. The next cathegory constitute "INDIVIDUALS TO WHOM THE CHILD WAS ENTRUSTED

\section{TO THE CARE"}

These persons were:

- a biological parent,

- distant family members,

- siblings,

- grandparents,

- a foster parent,

- a professional parent.

From the perspective of a family type in which the child with FASD diagnosis was placed, we have found out that a majority ( $63 \%$ ) of kids live in a foster care.

We have also found the necessary information about mother's use of alcohol during pregnancy in the court sentence on entrusting a child to a foster personal care where the biological mother's statement was recorded:

"...I drank only until I knew I was pregnant which I have found out only in the fourth month of pregnancy. Sometimes when I was pregnant I had an occasional cup of red wine because I craved it, I would drink 1-2 cups..."

This information helped the members of FAS diagnostic team to accurately assign a value to the last digit of a diagnostic code.

Father's statement about mother's drinking during pregnancy was an alternative way of data recording:

"...I, signed below M. B., declare that I witnessed that biological mother of our son KB, born in 2008, frequently used drinks containing alcohol. During pregnancy, as I remember, she used a beer and also visited different pubs. This situation continued also after the birth of son K. I refer this statement to the use of FAS diagnosis of my son as a part of a diagnostic documentation..."

In most cases we have obtained a statement from the foster parents: 
1. "...we do not know about biologial mother's use of alcohol during pregnancy..."

2. "...data about the use of alcohol during pregnancy are provided by older siblings..."

3. "...my friend who is from the same village as our foster child confirmed that his biological mother used alcohol during pregnancy..."

4. "...we do not have material, only insinuations in email exchange: ...information about smoking and maybe an alcohol during pregnancy..."

5. "...we do not know anything about alcohol, mother only admitted a smoking..."

6. "...we do not know, we do not have information..."

7. "...we have nothing, the data about mother are missing..."

The percentage of the fourth digit assigned to diagnosed children is rendered in the following table:

Table no. 3 The percentage of the fourth digit assigned to a diagnostic code

\begin{tabular}{|c|c|c|c|}
\hline $\begin{array}{c}\text { 4-digit } \\
\text { diagnostic code }\end{array}$ & $\begin{array}{l}\text { Cathegory for prenatal } \\
\text { alcohol exposure }\end{array}$ & $\begin{array}{l}\text { Description of alcohol use } \\
\text { during pregnancy }\end{array}$ & $\begin{array}{l}\text { Percentage of a code } \\
\text { selection for diagnosed } \\
\text { children }\end{array}$ \\
\hline 4 & High risk & $\begin{array}{l}\text { The use of alcohol during } \\
\text { pregnancy is CONFIRMED. } \\
\text { The scheme of exposition agrees } \\
\text { with medical literature and } \\
\text { describes foetus as "high risk" } \\
\text { (mostly high concentrations } \\
\text { of alcohol in blood taken at } \\
\text { least once a week during early } \\
\text { pregnancy). }\end{array}$ & $11 \%$ \\
\hline 3 & Some risk & $\begin{array}{l}\text { The use of alcohol during } \\
\text { pregnancy is CONFIRMED. } \\
\text { The amount of alcohol use is less } \\
\text { than in the previous value (4), } \\
\text { or the amount is unknown. }\end{array}$ & $33 \%$ \\
\hline 2 & Unknown risk & $\begin{array}{l}\text { The use of alcohol during } \\
\text { pregnancy is UNKNOWN. }\end{array}$ & $56 \%$ \\
\hline 1 & No risk & $\begin{array}{l}\text { It is confirmed that during the } \\
\text { period from conception to birth } \\
\text { the use of alcohol during } \\
\text { pregnancy did not exist. }\end{array}$ & - \\
\hline
\end{tabular}

Source: developed according to Astley, S. J., p. 41, 2004

Alcohol exposure is evaluated according to a quantity, timing, frequency, and evidence of exposure during pregnancy (see table 3). Case studies of the four values deal with two important issues: 1) an information regarding alcohol exposure in clinical environment may not be sufficiently available or may be available with indefinite accuracy and 2) precise consensus which would in a most accurate manner determine the amount of alcohol which might be actually toxic, for each individual foetus is currently not available (Stratton et al., 1996).

From the final four digits, with a focus on a determination of the fourth digit, we have found out that $56 \%$ of children have been assigned with a digit "2" - Unknown risk - The use of alcohol during pregnancy is UNKNOWN. 


\section{Discussion}

From the findings in documents of 19 children, collected within a period of two years, we have identified basic nature of our research sample. Therefore, we are claiming that the main target group of clients in our centre consists of children - boys and girls - within the range of 4.3-22 years. The main group was formed by children within the range of 6.1-10 years from the Roma and half-Roma origin (67 \%). The remaining sample came from europoid ethnicity. At the time, the diagnosed children were placed in foster care (83.5 \% - caregiving, adoption, personal care) or in an institutional care (31.5\%). The kids were mainly born in the middle part of Slovakia (58 \%), eastern Slovakia (25\%) and (only $17 \%$ ) in other regions of the country. Mental abilities were ranging between the mean (58 \%) and mild mental retardation (42\%).

Information about mother's drinking during pregnancy, obtained from the specialists were found out in the documents of social workers, healthcare workers and pedagogical workers.

- Social workers usually form their statements carefully, at times even vaguely, without a specific mentioning of the fact or an amount of alcohol. The old social care documentation does not state the fact at all.

- The way in which healthcare workers report the date is non-uniform.

- Pedagogical workers document the date through the transcript of documents and information delivered by foster parents.

At interviews with foster parents and transcripts of FASD questionnaires we have noted that the parents did not receive the information, respectively, it was not stated in the social report of a child listed in the registry of children suitable for adoption or foster care. By repeated demand of the information the competent authority refused to deliver this information.

We did assign our sample the value of the fourth digit "2". This means that $56 \%$ of mother's alcohol use during pregnancy is UNKNOWN. 33 \% of children had a CONFIRMED mother's alchohol use during pregnancy however, the amount of alcohol used was UNKNOWN (the assigned value thus became 3 ). $11 \%$ of children were exposed to alcohol prenatally and there was a high risk of toxicity during the prenatal stage of their development. The assigned number was "4" which means that mother's use of alcohol during pregnancy and the amount was CONFIRMED. The pattern of exposure agrees with medical literature and defines a foetus as "high risk" (mostly high concentrations of alcohol in blood taken at least once a week during early pregnancy).

\section{Conclusions and recommendations for practice}

According to study we recommend systemic measures to be taken for two target groups. Specialists and foster parents. We have structured the recommendations in two levels: education and experience:

For the specialists we suggest an implementation of education. Conceptually, it would be suitable that the universities and colleges accredited several postgradual programs which would follow the sectoral legislation and needs of target group of specialists. For the sector of social affairs, the act is the Act on Social Work, no. 219/2014. Mainly in §5-6, §13 and the part III - on ACCREDITATION 
OF SUBSPECIALIZED EDUCATIONAL PROGRAM AND TRAINING PROGRAM (http:// www.employment.gov.sk/). Because we are talking about 10-year old Roma or half-Roma children we recommend that the special education be focused on this age and ethnic group. We also suggest that the education of counsellors-specialists concentrates on a foster care.

Department of healthcare "according to the Act on healthcare providers (no. 578/2004, as amended) the lifelong education is an obligation of a healthcare worker. He/she may undergo a specialisation study or a certificate preparation in an accredited education institution but mainly by completing specific units of systematic education which is defined in the government regulation on a method of further education of healthcare workers (no. 322/2006 the Act as amended)." (http://www.health. gov.sk). The cited act also adds that the systematic education of a healthcare worker should be ongoing, registered and evaluated by a medical professional organisation according to the decree of Ministry of Healthcare no. 366/2005 (http://www.health.gov.sk).

The education of pedagogical workers should focus on the diagnosis itself which is the result of the four digits. The professionals, psychologists, speech therapists, special educators and social educators should also be able to recognize a child who is at risk of FASD. We came to this conclusion based on our experience that children with FASD are often incorrectly integrated in the schools. The education in this department is divided to lifelong and continuous (https://www.minedu.sk/). We recommend the use of postgradual education - continuous. The main focus of the specific programs should be on a narrowly profiled professional preparation of students who are assigned to a work position of a professional according to an Act of NR SR no. 317/2009, the Act on Pedagogical Employees and Professional Employees and on a change and completion of policy for a diagnostics, therapy and prevention of FAS/FASD followed by the education of pupils in daycares, elementary and secondary schools who are, disabled and performed in specific schools according to the Act NR SR no. 245/2008, the act about education and schooling (the school act) and about changes and completion of several acts. Educational program should respond to approved strategic documents of Slovak Republic in the department of Ministry of education, science, research and sports for the period of 2013-2020.

These are the primary documents:

- Concept of education and training for children with disability,

- Concept of special education guidance,

- National child action plan for years 2013-2017,

- National program for life conditions development for disabled citizens in all aspect of life,

- Criminality and other antisocial activity strategy in Slovak Republic for years 2012-2015,

- National program for the care of children and adolescents in Slovak Republic for years 2008-2015,

- National drug strategy for the period of 2013-2020,

- Health support national program.

The focus should be on a proper training of the field workers in order to improve the experience and effectivity of social workers. The training should aim for the quality and accuracy of recording the data regarding mother's use of alcohol. It is necessary to ensure that the data is recorded in a mandatory written documentation. We are suggesting to use the examination in order to evaluate the child's needs and level of a child's risk in a family. We also recommend that the issue of FASD 
be dealt by an office sheltered under the Social Affairs Department - specifically - the National Coordination Centre for a prevention of violence on children (NKS for RPNnD). This centre was established in 2014 as a branch of Ministry of Labour, Social Affairs and Family of SR. The institution is the outcome of National strategy goal for a child's protection against violence which the government of Slovak Republic approved in 2014. The aim was to present the issue of domestic violence to the public and provide an information on help options (http://detstvobeznasilia.gov.sk). For the healthcare providers - gynecologists, neonatologists, geneticists, pediatricians - the aim is a preparation of a screening policy and methodology the result of which would be the data being a part of mother's and child's health documentation. We recommend WHO Country Office in the Slovak Republic to be a responsible authority.

A sufficient experience should prepare pegagogical workers and deliver specialists who would be capable to implement and perform new diagnostic, therapeutic, preventive, educational and instructive methods in the area of school and social adaptation, integration and inclusion of students with mental and multiple disabilities caused by a toxic exposure to alcohol during their prenatal development. Techniques and methods will become a new and unique opportunity for improvement of inclusive education of such disabled students.

It is necessary to anchor the system settings in a policy within a framework of a dialogue and conception of all concerned departments.

A preparation area for foster parents and their guidance falls into the management of the department for social legal child protection and social caregiving. A foster parent needs to know the history and relationships in a family as well as the presence of socio-pathological features, genetic predisposition to specific types of disease which play a key role in health protection of a child growing up in a foster care. Therefore, we recommend new programs which would prepare foster parents to take care of a child with FASD. NÁVRAT and ÚSMEV AKO DAR are non-profit organisations in Slovakia which may become providers of such programs.

\section{References}

Act no. 219/2014 on Social Work. [online]. Accessed $7^{\text {th }}$ November 2015. http://www.employment. gov.sk/files/slovensky/uvod/legislativa/socialna-pomoc-podpora/219_2014.pdf.

Astley, S. J. (2004). Diagnostic Guide for Fetal Alcohol Spectrum Disorders: The 4-Digit Diagnostic Code. Third Edition. Seattle: University of Washington.

Astley, S. J. (2006). Comparison of the 4-Digit Diagnostic Code and the Hoyme Diagnostic Guidelines for Fetal Alcohol Spectrum Disorders. Pediatrics, 118(4), pp. 1532-1545.

Church, M. W., \& Kaltenbach, J. A. (1997). Hearing, Speech, Language, and Vestibular Disorders in the Fetal Alcohol Syndrome. Alcoholism: Clinical and Experimental Research, 21(3), pp. 495-512.

Dětské domovy a iné zariadenia [Orphanages and other facilities]. [online]. Accessed $15^{\text {th }}$ September 2015. http://www.upsvar.sk/detske-domovy-a-ine-zariadenia/detske-domovy/vybrane-statisticke-ukazovatele.html?page_id=130708. 
Doplňujúce pedagogické štúdium [Supplementary pedagogical education]. [online]. Accessed $26^{\text {th }}$ October 2015. https://www.minedu.sk/akreditacia-programov-doplnujuceho-pedagogickehostudia-a-programov-kontinualneho-vzdelavania/.

Fetal Alcohol Spectrum Disorders Fact Sheet. [online]. Accessed $14^{\text {th }}$ October 2015. https://report. nih.gov/nihfactsheets/Pdfs/FetalAlcoholSpectrumDisorders(NIAAA).pdf.

Grant, T. M., Huggins, J. E., Sampson, P. D., Ernst, C. C., Barr, H. M., \& Streissguth, A. P. (2009). Alcohol use before and during pregnancy in western Washington, 1989-2004: implications for the prevention of fetal alcohol spectrum disorders. American Journal of Obstetrics \& Gynecology, 200(3), pp. 278.e1-278.e8.

Hendl, J. (2005). Kvalitativní výzkum [Qualitative Research]. Praha: Portál.

Miles, M. B., \& Huberman, A. M. (1994). Qualitative Data Analysis. An Expanded Sourcebook. Sage Publ.

Mrázková, I., \& Brennerová, R. (2015). Právna úprava sociálnoprávnej ochrany detí a sociálnej kurately $v$ Slovenskej republike [Legislation for the Social Protection of Children and Social Guardianship in Slovakia]. Lecture. Kyjov: Sociálně pediatrický kongres [Socially Pediatric Congess], 23 ${ }^{\text {th }}$ September 2015.

Národná správa o ludskom rozvoji Slovenská republika 2001-2002 [National Report on Human Development Slovak Republic 2001-2002]. [online]. Accessed 14 ${ }^{\text {th }}$ September 2015. http://www. cphr.sk/undp2002.htm.

Národná stratégia na ochranu detí pred násilím [The National Strategy for the Protection of Children against Violence]. [online]. Accessed $5^{\text {th }}$ October 2015. http://detstvobeznasilia.gov.sk/index.php/ o-nas/.

Nosková, J. (2014). Manažment diagnostického centra fetálního alkoholového syndromu. Špecializačná práca. [Management of a Diagnostic Centre of the Fetal Alcohol Syndrome. Specialized work]. Slovak Medical University in Bratislava, Faculty of Public Health, Bratislava.

Okruhlica, L. (2012). Negatívne dopady nadmerného pitia na Slovensku [The negative impact of excessive drinking in Slovakia]. [online]. Accessed $5^{\text {th }}$ September 2015. http://www.euractiv.sk/ fileadmin/images/Brozura_Negativne_dopady_nadmerneho_pitia_na_Slovensku.pdf.

Overlapping Behavioral Characteristics \& Related Mental Health Diagnoses in Children. [online]. Accessed $5^{\text {th }}$ October 2015. http://www.mofas.org/wp-content/uploads/2014/05/OverlappingCharacteristics-1-19-15-CBT.pdf.

Silverman, D. (1994). Interpreting Qualitative Data. Methods for Analysing Talk, Text and Conversation. Sage Publ.

Straus, A., \& Corbinová, J. (1999).Základy kvalitatívneho výskumu [Basics of Qualitative Research]. Boskovice: Albert.

Streissguth, A. P., \& O’Malley, K. (2000). Neuropsychiatric implications and long-term consequences of Fetal Alcohol Spectrum Disorders. Seminars in Clinical Neuropsychiatry, 5(3), pp. 177-190. 
Streissguth, A. P., Baar, H. M., Bookstein, F. L., Sampson, P. D., \& Olson, H. C. (1999). The longterm neurocognitive consequences of prenatal alcohol: A 14-year study. Psychological Science, 10(3), pp. 186-190.

Streissguth, A. P., Bookstein, F. L., Barr, H. M., Sampson, P. D., O’Malley, K., \& Young, J. K. (2004). Risk factors for adverse life outcomes in Fetal Alcohol Syndrome and Fetal Alcohol Effects. Journal of Developmental \& Behavioral Pediatrics, 25(4), pp. 228-238.

Sústavné vzdelávanie zdravotníckych pracovníkov [Systematic education of heatlhcare workers]. [online]. Accessed 26 ${ }^{\text {th }}$ October 2015. http://www.health.gov.sk/?sustavne-vzdelavanie-zdravotnickychpracovnikov).

Švaříček, R., Šed'ová, K. et al. (2007) Kvalitatívní výzkum v pedagogických vědách [Qualitative Research in Educational Sciences]. Praha: Portál.

\section{Authors}

Mgr. PhDr. Ol'ga Okálová, PhD.

Center for Diagnostics, Therapy and Prevention of FAS

Specialized Scientific-Research Institute

Faculty of Education, Catholic University, Ružomberok

Department of Education and Psychology

Hrabovská cesta 1, 034 01, Ružomberok, Slovakia

olga.okalova@ku.sk

Mgr. Anna Kútniková

Center for Diagnostics, Therapy and Prevention of FAS

Specialized Scientific-Research Institute

Faculty of Education, Catholic University, Ružomberok

Department of Education and Psychology

Hrabovská cesta 1, 034 01, Ružomberok, Slovakia

anna.kutnikova@gmail.com

Ing. Zuzana Gejdošová, PhD.

Faculty of Education, Catholic University, Ružomberok

Vice-Dean for Education and Training

Hrabovská cesta 1, 034 01, Ružomberok, Slovakia

zuzana.gejdosova@ku.sk

PaedDr. Miroslav Pilát, Ph.D.

Faculty of Public Policies, Silesian University in Opava The Institute of Pedagogical and Psychological Sciences Bezručovo náměstí 885/14, 746 01, Opava, Czech Republic miroslav.pilat@fvp.slu.cz 